\title{
Response of broiler chickens to diets containing different levels of sodium with or without microbial phytase supplementation
}

\author{
Marjina Akter ${ }^{1 *}$, Hadden Graham ${ }^{2}$ and Paul Ade $\mathrm{ji}^{3,4}$ \\ Khulshi-4225, Chittagong, Bangladesh \\ ${ }^{2}$ AB Vista, 3 Woodstock Court, Marlborough Wiltshire SN8 4AN, UK \\ ${ }^{3}$ School of Environmental and Rural Science, University of New England, Armidale, NSW 2351, Australia \\ ${ }^{4}$ College of Agriculture, Fisheries and Forestry, Fiji National University, P.O. Box-1544, Nausori, Fiji
}

${ }^{1}$ Dairy and Poultry Science Department, Faculty of Veterinary Medicine, Chittagong Veterinary and Animal Sciences University,

\begin{abstract}
Phytate induced excessive mineral excretion through poultry litter leads to poor performance and environmental pollution. Exogenous microbial phytase supplementation to poultry diets reduce the environmental excretion of nutrient and improve bird's performance. However, excessive dietary sodium $(\mathrm{Na})$ level may hinder the phytase-mediated phytate hydrolysis and negate the beneficial effects of phytase. Therefore, this experiment was conducted to investigate the effects of different concentration dietary $\mathrm{Na}$ on phytase activity and subsequent impact on broiler performance, bone mineralisation and nutrient utilisation. In this study, six experimental diets, consisting of three different levels of $\mathrm{Na}(1.5,2.5$, or $3.5 \mathrm{~g} / \mathrm{kg}$ ) and two levels of microbial phytase $(0$ or $500 \mathrm{U} / \mathrm{kg}$ ) were formulated by using $3 \times 2$ factorial design. The six experimental diets were offered to 360 day-old Ross 306 male chicks for 35 days, where, each experimental diet consisted of 6 replicates groups with 10 birds. Along with growth performance, nutrient utilization, intestinal enzyme activity, dry matter (DM) content of litter and mineral status in bone were analysed. Dietary $\mathrm{Na}$ and phytase had no effect on bode weight gain and feed intake. Birds on the low $\mathrm{Na}$ diet showed higher $(p<0.05)$ feed conversion ratio $(\mathrm{FCR})$ than the mid-Na diets. High dietary Na adversely affected $(p<0.001)$ excreta DM content. Phytase supplementation to the high-Na diet increased $(p<0.01)$ the litter ammonia content. High dietary $\mathrm{Na}$ with phytase supplementation improved $(\mathrm{Na} \times$ phytase, $p<0.05)$ the AME value and ileal digestibility of $\mathrm{Ca}$ and $\mathrm{Mg}$. The total tract retention of $\mathrm{Ca}, \mathrm{P}$, and $\mathrm{Mg}$ was reduced with high $\mathrm{Na}$ diet, which was counteracted by phytase supplementation $(\mathrm{Na} \times$ phytase, $p<0.001)$. The diets containing mid-level of $\mathrm{Na}$ improved $(p<0.001)$ the function of $\mathrm{Na}-\mathrm{K}$ ATPase and Mg-ATPase in the jejunum. The overall results indicate that high dietary Na did not affect phytase activity but influenced the nutrient utilization of birds, which was not reflected in bird overall performance.
\end{abstract}

Keywords: Broilers, Phytate, Phytase, Uric acid, Digestibility

\section{Background}

Sodium plays an important role in regulating different physio- logical functions in broiler chickens. Along with potassium and chlorine, the other regulators of dietary electrolyte balance (DEB), $\mathrm{Na}$ is of utmost importance for tissue protein synthesis, cellular

Received: Jan 31,2019 Revised: Mar 12, 2019 Accepted: Mar 15, 2019

"Corresponding author: Marjina Akter, Dairy and Poultry Science Department, Faculty of Veterinary Medicine, Chittagong Veterinary and Animal Sciences University, Khulshi-4225, Chittagong, Bangladesh.

Tel: +88-01719198226, E-mail: marjinajahivet@gmail.com

This is an Open Access article distributed under the terms of the Creative Commons Attribution Non-Commercial License (http://creativecommons.org/licenses/bync/4.0/) which permits unrestricted non-commercial use, distribution, and reproduction in any medium, provided the original work is properly cited.

Copyright (C) 2019 Korean Society of Animal Science and Technology. 
homeostasis and the body's acid-base balance, to ensure optimum performance of broilers [1]. DEB may be defined by the following formula: $\mathrm{DEB}(\mathrm{mEq} / \mathrm{kg})=\mathrm{Na}^{+}+\mathrm{K}^{+}-\mathrm{Cl}^{-}$and $250 \mathrm{mEq} / \mathrm{kg}$ of DEB is suggested to be optimum for broiler growth and litter quality [2]. The intestinal uptake and absorption of different nutrients, particularly glucose and amino acids, are influenced by $\mathrm{Na}$ because of its involvement in $\mathrm{Na}$-dependent transport systems and $\mathrm{Na}-\mathrm{K}-\mathrm{ATPase}$ activity $[3,4]$. Low $\mathrm{Na}$ can have a negative impact on broiler performance [2], whereas mortality rate and wet litter problems are increased by excess $\mathrm{Na}$ in diets [5]. Although, in 1994, the NRC [6] recommended 2.0 and $1.5 \mathrm{~g} / \mathrm{kg} \mathrm{Na}$ in starter and grower chicken diets, uncertainty exists about the optimum level of $\mathrm{Na}$ necessary for maximum performance.

Exogenous microbial phytase is commonly used in poultry diets to replace inorganic phosphates and reduce the anti-nutrient effect of phytate. The benefit of phytase supplementation on diet costs, bird performance, nutrient utilization and reduction of $\mathrm{P}$ loss to the environment is well recognized. Despite its beneficial effect on broiler performance, the full benefits of phytase have not yet been achieved due to different influential factors. Dietary mineral concentrations are considered to be one of the important factors that can regulate the activity of dietary phytase [7]. Previous in vitro study [8] showed that high $\mathrm{Na}$ concentration $(3.5 \mathrm{~g} / \mathrm{kg})$ significantly lowered phytate hydrolysis by phytase at $\mathrm{pH} 2.5$.

Phytase supplementation could reduce the phytate-induced $\mathrm{Na}$ hypersecretion from intestine and subsequently influence the protein/amino acid digestibility $[9,10]$. But, higher DEB or Na concentration could mute the anti-nutritive effect of phytate, resulting in a lower phytase response on nutrient digestibility [11,12]. Although, the influence of phytase supplementation on litter quality has not yet been established, but some field studies have indicated the occurrence of the phytase-induced increased moisture content in excreta [13].

Therefore, the objective of the present study was to investigate the possible effect of $\mathrm{Na}$ on phytase activity, with a focus on broiler growth performance, litter quality and nutrient utilization.

\section{Materials and Methods}

\section{Experimental design and bird management}

In the present study, a $3 \times 2$ factorial arrangement was used to investigate the effect of different levels of dietary $\mathrm{Na}(1.5,2.5$, and 3.5 $\mathrm{g} / \mathrm{kg}$ ) with or without microbial phytase supplementation on overall performance of broilers up to 35 days of age. Three hundred and sixty day-old Ross 308 male broiler chicks (40.04 $\pm 0.70 \mathrm{~g}$ ) from a local commercial hatchery (Baiada Poultry Pty. Ltd., Tamworth, Australia) were randomly allocated to six treatment diets. Each diet was replicated six times, with 10 birds per replicate. All the birds were distributed randomly in an environmentally controlled house, with three banks of multi-tiered brooder cages $(600 \times 420$ $\times 23 \mathrm{~cm})$. The detailed description of bird management has been described in a previous study(Table 1,2 and 3) [14].

\section{Dietary treatments}

Six experimental diets were formulated with low, medium and high levels of $\mathrm{Na}(1.5,2.5$, and $3.5 \mathrm{~g} / \mathrm{kg}$, respectively) with or without exogenous microbial phytase ( 0 or $500 \mathrm{U} / \mathrm{kg}$ ). The diets were coded as LS - low Na, MS - Medium Na, HS - High Na, LSP -

Table 1. Ingredient and nutrient specifications of starter diets (0-10 days)

\begin{tabular}{|c|c|c|c|c|c|c|}
\hline \multirow{2}{*}{$\begin{array}{l}\text { Ingredient composition } \\
(\mathrm{g} / \mathrm{kg})\end{array}$} & \multicolumn{6}{|c|}{ Diets } \\
\hline & LS & MS & HS & LSP & MSP & HSP \\
\hline Corn & 570.1 & 563.1 & 556.1 & 586.9 & 579.9 & 572.9 \\
\hline Soybean meal & 338.0 & 338.8 & 339.5 & 336.2 & 337.0 & 337.7 \\
\hline Meat meal & 24.6 & 25.0 & 25.4 & 23.6 & 24.0 & 24.5 \\
\hline Canola oil & 26.4 & 28.7 & 31.0 & 21.0 & 23.3 & 25.5 \\
\hline Limestone & 11.2 & 11.1 & 11.1 & 11.4 & 11.4 & 11.3 \\
\hline Di-calcium phosphate & 15.1 & 15.1 & 15 & 7.3 & 7.2 & 7.1 \\
\hline Salt & 1.5 & 1.5 & 1.6 & 1.5 & 1.5 & 1.5 \\
\hline Sodium bicarbonate & 1.9 & 5.5 & 9.2 & 0.8 & 4.5 & 8.2 \\
\hline Premix ${ }^{1)}$ & 2.0 & 2.0 & 2.0 & 2.0 & 2.0 & 2.0 \\
\hline Choline $\mathrm{Cl}$ & 0.9 & 0.9 & 0.9 & 0.9 & 0.9 & 0.9 \\
\hline L-Lysine $\mathrm{HCl}$ & 3.0 & 3.0 & 3.0 & 3.0 & 3.0 & 3.0 \\
\hline DL-Methionine & 4.1 & 4.1 & 4.1 & 4.1 & 4.1 & 4.1 \\
\hline L-Threonine & 1.9 & 1.9 & 1.9 & 1.9 & 1.9 & 1.9 \\
\hline Phytase (U/kg of diet) & 0 & 0 & 0 & 500 & 500 & 500 \\
\hline \multicolumn{7}{|l|}{ Calculated values $(\mathbf{g} / \mathbf{k g})^{2)}$} \\
\hline Calcium & 9.6 & 9.6 & 9.6 & 9.6 & 9.6 & 9.6 \\
\hline Total phosphorus & 7.2 & 7.2 & 7.2 & 7.2 & 7.2 & 7.2 \\
\hline Available phosphorus & 4.8 & 4.8 & 4.8 & 4.8 & 4.8 & 4.8 \\
\hline Sodium & 1.5 & 2.5 & 3.5 & 1.5 & 2.5 & 3.5 \\
\hline Potassium & 9.51 & 9.50 & 9.50 & 9.52 & 9.51 & 9.5 \\
\hline Chloride & 2.27 & 2.30 & 2.30 & 2.28 & 2.28 & 2.28 \\
\hline \multicolumn{7}{|l|}{ Analysed values (g/kg) } \\
\hline Calcium & 10.1 & 10.0 & 9.8 & 10.3 & 9.9 & 9.7 \\
\hline Total phosphorus & 7.1 & 7.0 & 7.2 & 6.3 & 6.2 & 6.1 \\
\hline Sodium & 1.5 & 2.4 & 3.5 & 1.3 & 2.3 & 3.3 \\
\hline Phytase (U/kg) & 30 & 38 & 42 & 550 & 545 & 550 \\
\hline
\end{tabular}

${ }^{1)}$ Supplied per $\mathrm{kg}$ of diet $(\mathrm{mg})$ : 11,998.8 IU vitamin A (as all-trans retinol); 3,600 IU cholecalciferol; $65.56 \mathrm{IU}$ vitamin $\mathrm{E}$ (as d-a-tocopherol); $2 \mathrm{mg}$ vitamin $\mathrm{K}_{3} ; 2 \mathrm{mg}$ thiamine; $6 \mathrm{mg}$ riboflavin; $5 \mathrm{mg}$ pyridoxine hydrochloride; $0.2 \mathrm{mg}$ vitamin $\mathrm{B}_{12} ; 0.1 \mathrm{mg}$ biotin; $50 \mathrm{mg}$ niacin; $12 \mathrm{mg}$ D-calcium pantothenate; $2 \mathrm{mg}$ folic acid; $80 \mathrm{mg} \mathrm{Mn;60}$ $\mathrm{mg} \mathrm{Fe} ; 8 \mathrm{mg} \mathrm{Cu} ; 1 \mathrm{mg} \mathrm{l} ; 0.3 \mathrm{mg} \mathrm{Co} ; 1 \mathrm{mg} \mathrm{Mo.}$

${ }^{2)}$ All diets were formulated to contain $12.6 \mathrm{MJ} / \mathrm{kg}$ metabolizable energy; $230 \mathrm{~g} / \mathrm{kg}$ crude protein; $5.1 \mathrm{~g} / \mathrm{kg}$ digestible methionine; $12.8 \mathrm{~g} / \mathrm{kg}$ digestible lysine; $9.5 \mathrm{~g} / \mathrm{kg}$ digestible methionine + cysteine; $8.6 \mathrm{~g} / \mathrm{kg}$ digestible threonine, $13.7 \mathrm{~g} / \mathrm{kg}$ digestible arginine. LS, low Na; MS, mid Na; HS, high Na; LSP, low Na with phytase; MSP, mid Na with phytase; HSP, high Na with phytase. 
Table 2. Ingredient and nutrient specifications of grower diets (11-24 days)

\begin{tabular}{|c|c|c|c|c|c|c|}
\hline \multirow{2}{*}{$\begin{array}{l}\text { Ingredient } \\
\text { composition (g/kg) }\end{array}$} & \multicolumn{6}{|c|}{ Diets } \\
\hline & LS & MS & HS & LSP & MSP & HSP \\
\hline Corn & 598.3 & 590.8 & 583.3 & 615.2 & 607.8 & 600.4 \\
\hline Soybean meal & 282.0 & 283.4 & 284.7 & 280.2 & 281.4 & 282.7 \\
\hline Meat meal & 50.0 & 50.0 & 50.0 & 49.0 & 49.1 & 49.2 \\
\hline Canola oil & 38.7 & 41.1 & 43.5 & 33.2 & 35.6 & 38 \\
\hline Limestone & 6.3 & 6.3 & 6.3 & 6.6 & 6.6 & 6.5 \\
\hline Dicalcium phosphate & 7.9 & 7.9 & 7.9 & 0 & 0 & 0 \\
\hline Salt & 1.5 & 1.5 & 1.5 & 1.5 & 1.5 & 1.5 \\
\hline Sodium bicarbonate & 1.4 & 5.1 & 8.8 & 0.3 & 4 & 7.7 \\
\hline $\mathrm{TiO}_{2}$ & 5.0 & 5.0 & 5.0 & 5.0 & 5.0 & 5.0 \\
\hline Premix ${ }^{1)}$ & 2.0 & 2.0 & 2.0 & 2.0 & 2.0 & 2.0 \\
\hline Choline $\mathrm{Cl}$ & 1.0 & 1.0 & 1.0 & 1.0 & 1.0 & 1.0 \\
\hline L-Lysine $\mathrm{HCl}$ & 1.9 & 1.9 & 1.9 & 2.0 & 1.9 & 1.9 \\
\hline DL-Methionine & 3.4 & 3.4 & 3.4 & 3.4 & 3.4 & 3.4 \\
\hline L-Threonine & 1.4 & 1.4 & 1.4 & 1.4 & 1.4 & 1.4 \\
\hline Phytase (U/kg diet) & 0 & 0 & 0 & 500 & 500 & 500 \\
\hline
\end{tabular}

\begin{tabular}{lllllll}
\hline${\text { Calculated values } \mathbf{( g / k g )})^{2}}^{2}$ & & & & & & \\
Calcium & 8.7 & 8.7 & 8.7 & 8.7 & 8.7 & 8.7 \\
Available phosphorus & 4.4 & 4.4 & 4.4 & 4.4 & 4.4 & 4.4 \\
Total phosphorus & 6.7 & 6.7 & 6.7 & 6.7 & 6.7 & 6.7 \\
Sodium & 1.5 & 2.5 & 3.5 & 1.5 & 2.5 & 3.5 \\
Potassium & 8.5 & 8.5 & 8.5 & 8.5 & 8.5 & 8.5 \\
Chloride & 2.2 & 2.2 & 2.2 & 2.2 & 2.2 & 2.2 \\
\hline
\end{tabular}

\section{Analysed values ( $\mathrm{g} / \mathrm{kg})$}

\begin{tabular}{lllllll} 
Calcium & 8.9 & 9.0 & 8.9 & 8.9 & 8.8 & 8.6 \\
Total phosphorus & 7.1 & 6.9 & 7.0 & 5.6 & 5.6 & 5.8 \\
Sodium & 1.5 & 2.6 & 3.5 & 1.4 & 2.4 & 3.4 \\
Phytase (U/kg) & 40 & 38 & 45 & 550 & 565 & 559 \\
\hline
\end{tabular}

${ }^{1)}$ Supplied per $\mathrm{kg}$ of diet $(\mathrm{mg})$ : 11,998.8 IU vitamin A (as all-trans retinol); 3,600 IU cholecalciferol; $65.56 \mathrm{IU}$ vitamin $\mathrm{E}$ (as d-a-tocopherol); $2 \mathrm{mg}$ vitamin $\mathrm{K}_{3} ; 2 \mathrm{mg}$ thiamine; $6 \mathrm{mg}$ riboflavin; $5 \mathrm{mg}$ pyridoxine hydrochloride; $0.2 \mathrm{mg}$ vitamin $\mathrm{B}_{12} ; 0.1 \mathrm{mg}$ biotin; $50 \mathrm{mg}$ niacin; $12 \mathrm{mg}$ D-calcium pantothenate; $2 \mathrm{mg}$ folic acid; $80 \mathrm{mg} \mathrm{Mn;} 60$ $\mathrm{mg} \mathrm{Fe} ; 8 \mathrm{mg} \mathrm{Cu} ; 1 \mathrm{mg} \mathrm{l} ; 0.3 \mathrm{mg} \mathrm{Co} ; 1 \mathrm{mg} \mathrm{Mo}$.

${ }^{2)}$ All diets were formulated to contain $13.2 \mathrm{MJ} / \mathrm{kg}$ metabolisable energy; $215 \mathrm{~g} / \mathrm{kg}$ crude protein; $4.7 \mathrm{~g} / \mathrm{kg}$ digestible methionine; $11.5 \mathrm{~g} / \mathrm{kg}$ digestible lysine; $8.7 \mathrm{~g} / \mathrm{kg}$ digestible methionine + cysteine; $7.7 \mathrm{~g} / \mathrm{kg}$ digestible threonine, $12.3 \mathrm{~g} / \mathrm{kg}$ digestible arginine.

LS, low Na; MS, mid Na; HS, high Na; LSP, low Na with phytase; MSP, mid Na with phytase; HSP, high Na with phytase.

Low Na with phytase, MSP - Medium Na with phytase and HSP - High Na with phytase. The mineral matrix (1.5 g/ $/ \mathrm{kg}$ AvP, $1.65 \mathrm{~g} /$ $\mathrm{kg} \mathrm{Ca} \& 0.35 \mathrm{~g} / \mathrm{kg} \mathrm{Na}$ ) of the commercial microbial phytase product, derived from modified Escherichia coli 6- phytase expressed in Trichoderma reesei (Quantum Blue, AB Vista, Marlborough, UK) were applied in phytase-supplemented diets to achieve the $\mathrm{Ca}, \mathrm{AvP}$, and $\mathrm{Na}$ levels. The activity of the phytase was $5,000 \mathrm{U} / \mathrm{g}$ where a unit $(\mathrm{U})$ is defined as the quantity of enzyme that liberates one $\mu \mathrm{mol}$ of inorganic $\mathrm{P}$ per minute from sodium phytate at $\mathrm{pH}$
Table 3. Ingredient and nutrient specifications of finisher diets (25-35 days)

\begin{tabular}{|c|c|c|c|c|c|c|}
\hline \multirow{2}{*}{$\begin{array}{l}\text { Ingredient } \\
\text { composition (g/kg) }\end{array}$} & \multicolumn{6}{|c|}{ Diets } \\
\hline & LS & MS & HS & LSP & MSP & HSP \\
\hline Corn & 629.4 & 622.9 & 615.9 & 627.6 & 631.6 & 624.2 \\
\hline Soybean meal & 259.7 & 259.8 & 260.5 & 283.6 & 269.1 & 270.4 \\
\hline Meat meal & 48.7 & 49.5 & 50.0 & 31.4 & 41.5 & 41.5 \\
\hline Canola oil & 40.1 & 42.2 & 44.5 & 39.6 & 38.9 & 41.3 \\
\hline Limestone & 6.1 & 6.0 & 5.9 & 7.9 & 6.9 & 6.9 \\
\hline Dicalcium phosphate & 6.7 & 6.5 & 6.5 & 1.9 & 0 & 0 \\
\hline Salt & 2.0 & 2.0 & 2.0 & 2.0 & 2.0 & 2.0 \\
\hline Sodium carbonate & 0.7 & 4.4 & 8.1 & 0 & 3.5 & 7.2 \\
\hline Premix ${ }^{1)}$ & 2.0 & 2.0 & 2.0 & 2.0 & 2.0 & 2.0 \\
\hline Choline $\mathrm{Cl}$ & 0.9 & 0.9 & 0.9 & 0.8 & 0.9 & 0.9 \\
\hline L-Lysine $\mathrm{HCl}$ & 0.9 & 0.9 & 0.9 & 0.6 & 0.8 & 0.8 \\
\hline DL-Methionine & 2.7 & 2.8 & 2.8 & 2.6 & 2.7 & 2.7 \\
\hline L-Threonine & 0.8 & 0.8 & 0.8 & 0.7 & 0.8 & 0.8 \\
\hline Phytase (U/kg of diet) & 0 & 0 & 0 & 500 & 500 & 500 \\
\hline \multicolumn{7}{|l|}{ Calculated values $(\mathbf{g} / \mathbf{k g})^{2)}$} \\
\hline Calcium & 8.7 & 8.7 & 8.7 & 8.7 & 8.7 & 8.7 \\
\hline Available phosphorus & 4.4 & 4.4 & 4.4 & 4.4 & 4.4 & 4.4 \\
\hline Total phosphorus & 6.9 & 6.9 & 6.9 & 6.9 & 6.9 & 6.9 \\
\hline Sodium & 1.5 & 2.5 & 3.5 & 1.5 & 2.5 & 3.5 \\
\hline Potassium & 8.1 & 8.1 & 8.1 & 8.5 & 8.3 & 8.3 \\
\hline Chloride & 2.3 & 2.3 & 2.3 & 2.2 & 2.2 & 2.2 \\
\hline \multicolumn{7}{|l|}{ Analysed values ( $\mathbf{g} / \mathbf{k g})$} \\
\hline Calcium & 8.6 & 8.7 & 8.9 & 8.4 & 8.8 & 8.6 \\
\hline Total phosphorus & 7.2 & 7.4 & 7.0 & 5.8 & 5.8 & 5.4 \\
\hline Sodium & 1.4 & 2.5 & 3.6 & 1.5 & 2.3 & 3.3 \\
\hline Phytase (U/kg) & 40 & 45 & 42 & 550 & 526 & 538 \\
\hline
\end{tabular}

${ }^{1)}$ Supplied per $\mathrm{kg}$ of diet (mg): 11,998.8 IU vitamin A (as all-trans retinol); 3,600 IU cholecalciferol; $65.56 \mathrm{IU}$ vitamin $\mathrm{E}$ (as d-a-tocopherol); $2 \mathrm{mg}$ vitamin $\mathrm{K}_{3} ; 2 \mathrm{mg}$ thiamine; $6 \mathrm{mg}$ riboflavin; $5 \mathrm{mg}$ pyridoxine hydrochloride; $0.2 \mathrm{mg}$ vitamin $\mathrm{B}_{12} ; 0.1 \mathrm{mg}$ biotin; $50 \mathrm{mg}$ niacin; $12 \mathrm{mg} \mathrm{D-calcium} \mathrm{pantothenate;} 2 \mathrm{mg}$ folic acid; $80 \mathrm{mg} \mathrm{Mn} ; 60 \mathrm{mg}$ Fe; $8 \mathrm{mg} \mathrm{Cu} ; 1 \mathrm{mg} \mathrm{l} ; 0.3 \mathrm{mg} \mathrm{Co} ; 1 \mathrm{mg} \mathrm{Mo}$.

${ }^{2)}$ All diets were formulated to contain $13.4 \mathrm{MJ} / \mathrm{kg}$ metabolizable energy; $195 \mathrm{~g} / \mathrm{kg}$ crude protein; $4.3 \mathrm{~g} / \mathrm{kg}$ digestible methionine; $10.3 \mathrm{~g} / \mathrm{kg}$ digestible lysine; $8.0 \mathrm{~g} / \mathrm{kg}$ digestible methionine + cysteine; $6.9 \mathrm{~g} / \mathrm{kg}$ digestible threonine, $11.0 \mathrm{~g} / \mathrm{kg}$ digestible arginine. LS, low Na; MS, mid Na; HS, high Na; LSP, low Na with phytase; MSP, mid Na with phytase; HSP, high Na with phytase.

5.5 and $37^{\circ} \mathrm{C}$. In all grower diets, titanium oxide $(5 \mathrm{~g} / \mathrm{kg}$ diet) was added as an indigestible marker, to enable assessment of nutrient digestibility. Diets were formulated to be iso-energetic and iso-nitrogenous and were pelleted at $65^{\circ} \mathrm{C}$. Diets were pelleted between 3 and $4 \mathrm{~mm}$ diameter and used as such in the grower (11-24 d) and finisher (25-35 d) phases respectively. Diets were crumbled in the starter $(0-10 \mathrm{~d})$ phase. All diets were formulated to either meet or exceed the Aviagen, 2014 [15] nutrient recommendation and breed standards, except for $\mathrm{Na}$. 
Collection, processing and analysis of samples

On d 10, 24, and 35, feed intake (FI) and body weight (BW) were recorded. Mortality was recorded as it occurred. Feed conversion ratio (FCR) was calculated and corrected for mortality. From 22 to $24 \mathrm{~d}$, excreta samples were collected on cage basis over three consecutive days. Daily excreta collected were pooled; mixed thoroughly and subsamples were kept in a plastic container at $-20^{\circ} \mathrm{C}$ until further analysis. On d 24, two birds were randomly chosen from each cage and killed by cervical dislocation, to collect the ileal digesta, left tibia and jejunal tissue samples. The procedures of collection, processing and analysis of different samples (diets, ileal digesta, excreta, tibia bone, and parts of jejunum) for nutrient digestibility, bone quality, intestinal enzyme activities, phytase activity in diet were the same as documented previously $[14,16]$.

\section{Excreta ammonia and urea analysis}

The excreta samples collected on d 24 were analyzed to simulate the effect of the treatments on litter dry matter (DM), uric acid and ammonia concentration. In $50 \mathrm{~mL}$ plastic tubes, $5 \mathrm{~g}$ of excreta from each sample were taken and then $40 \mathrm{~mL}$ of Milli-Q water were added to each tube. After homogenizing for 2 mins $(1084 \times \mathrm{g})$, the samples were filtered through Whatman No. 1 filter paper and diluted 10 times. The filtrate was used for ammonia and uric acid measurements.

\section{Measurement of excreta uric acid and ammonia}

Uric acid content of the excreta was measured using colorimetric method as indicated [17]. Excreta ammonia was measured by following the procedure described in the ammonia assay kit (Catalogue Number AA0100, Sigma-Aldrich, and 3050 Spruce Street, Saint Louis, Missouri 63103, USA). Briefly, around 0.1 to $0.2 \mathrm{~mL}$ diluted excreta sample was placed into a cuvette and mixed thoroughly with 1-2 $\mathrm{mL}$ ammonia assay reagent, and then incubated for $5 \mathrm{~min}$ at $18^{\circ} \mathrm{C}-35^{\circ} \mathrm{C}$. After that, absorbance was read at 340 $\mathrm{nm}$ against blank samples (prepared with $0.1 \mathrm{~mL}$ water mixed with $1.0 \mathrm{~mL}$ ammonia assay reagent). After this reading, $0.01 \mathrm{~mL}$ of L-glutamate dehydrogenase solution (Catalogue Number-G2294) was added to each cuvette and incubated at $18^{\circ} \mathrm{C}-35^{\circ} \mathrm{C}$ for $5 \mathrm{~min}$. The absorbance of each solution was measured again at $340 \mathrm{~nm}$. The concentration of ammonia $(\mathrm{mg} / \mathrm{mL})$ was calculated from the following equations:

The $\Delta \mathrm{A} 340$ for the reagent blank, test and standard were determined. For each:

$\Delta \mathrm{A}_{340}=\mathrm{A}_{\text {initial }}-\mathrm{A}_{\text {final }} \Delta\left(\Delta \mathrm{A}_{340}\right)$ Test or standard

$=\Delta \mathrm{A}_{340}$ (Test or standard) $-\Delta \mathrm{A}_{340}$ (Blank) $\mathrm{mg}$ of $\mathrm{NH}_{3} / \mathrm{mL}$ of original sample

\section{$=\frac{(A)(T V)(M W \text { of ammonia) }(F)}{(\varepsilon)(d)(S V)(\text { Conversion factor of } \mu g \text { to } \mathrm{mg})}$}

$=\frac{(A)(T V)(17)(F)}{(6.22)(1)(S V)(1000)}$

$=\frac{(A)(T V)(F) \times 0.00273}{(S V)}$

where, A, $\Delta\left(\Delta \mathrm{A}_{340}\right)$ Test or standard; TV, Total assay volume $(\mathrm{mL})$; SV, sample volume $(\mathrm{mL}) ; \mathrm{MW}$ of ammonia, $17 \mathrm{~g} / \mathrm{mole} ; \mathrm{F}$, Dilution factor from sample preparation; $\mathcal{E}$, Millimolar extinction coefficient for NADPH at $340 \mathrm{~nm}$; d, Light path $(1 \mathrm{~cm})$.

\section{Statistical analysis}

The data were analysed as a $3 \times 2$ factorial ANOVA using the GLM procedure of Minitab software (Minitabe 16.0, Minitab Inc., State College, Pennsylvania, USA, 2010) for the main effects of $\mathrm{Na}$ and phytase, along with their interactions. Separation of means within a significant effect was conducted using Tukey's HSD test. The significance of difference between means was determined by Fisher's least significant difference at $p \leq 0.05$.

\section{Results}

\section{Growth performance}

The analysed levels of total $\mathrm{P}, \mathrm{Ca}, \mathrm{Na}$ and phytase level in the feed were in close agreement with calculated values (Tables 1,2, and 3). Dietary $\mathrm{Na}$, phytase and their interaction had no effect $(p>0.05)$ on FI and body weight gain (BWG) at any phase of rearing (Table 4). Phytase supplementation tended ( $p=0.076)$ to improve BWG during 1-24 d. The FCR of birds was not affected by $\mathrm{Na}$ and phytase over the experimental period except from $\mathrm{d} 0$ to 10 . During this stage, mid-Na diets improved $(p<0.05)$ the FCR compared to low-Na diets. At all stages of rearing, the interaction between $\mathrm{Na}$ and phytase had no significant effect on FCR.

lleal pH, excreta DM, ammonia and uric acid concentration Results shown in Table 5 indicate that there was no significant effect of $\mathrm{Na}$ and phytase supplementation on ileal $\mathrm{pH}$. None of the interaction effects was significant, except for excreta ammonia. Phytase supplementation to low and high $\mathrm{Na}$ diets increased (Na $\times$ phytase, $p<0.007)$ the ammonia excretion compared to phytase free diets. The ammonia excretion was not differed in phytase supplemented diets irrespective of $\mathrm{Na}$ levels. The high $\mathrm{Na}(3.5 \mathrm{~g} / \mathrm{kg})$ diets lowered $(p<0.001)$ the excreta DM, whereas the reverse $(p<$ 0.001 ) was the case for uric acid concentration. 
Table 4. Influence of dietary Na levels with or without microbial phytase on feed intake (FI), body weight gain (BWG) and feed conversion ratio (FCR) of broilers fed from day 0 to 35

\begin{tabular}{|c|c|c|c|c|c|c|c|c|c|c|}
\hline \multirow{2}{*}{$\begin{array}{c}\mathrm{Na} \\
\text { level }^{1)}\end{array}$} & \multirow{2}{*}{ Phytase $^{2)}$} & \multicolumn{3}{|c|}{ FI (g/bird) } & \multicolumn{3}{|c|}{ BWG (g/bird) } & \multicolumn{3}{|c|}{ FCR } \\
\hline & & $1-10 d$ & $1-24 d$ & $1-35 d$ & $1-10 d$ & $1-24 d$ & $1-35 d$ & $1-10 d$ & $1-24 d$ & $1-35 d$ \\
\hline \multirow[t]{2}{*}{ Low } & None & 248.9 & $1,644.5$ & $3,486.3$ & 216.7 & $1,230.0$ & $2,400.7$ & 1.15 & 1.33 & 1.45 \\
\hline & Plus & 257.9 & $1,688.8$ & $3,502.3$ & 219.7 & $1,256.5$ & $2,405.5$ & 1.17 & 1.34 & 1.46 \\
\hline \multirow[t]{2}{*}{ Mid } & None & 250.0 & $1,631.9$ & $3,432.4$ & 222.2 & $1,246.4$ & $2,367.7$ & 1.13 & 1.32 & 1.45 \\
\hline & Plus & 240.2 & $1,677.8$ & $3,460.2$ & 216.7 & $1,332.9$ & $2,291.0$ & 1.11 & 1.26 & 1.51 \\
\hline \multirow[t]{2}{*}{ High } & None & 244.5 & $1,640.0$ & $3,418.2$ & 213.6 & $1,262.1$ & $2,295.2$ & 1.14 & 1.30 & 1.49 \\
\hline & Plus & 238.3 & $1,662.5$ & $3,339.8$ & 222.9 & $1,303.9$ & $2,312.0$ & 1.12 & 1.27 & 1.45 \\
\hline SEM & & 11.5 & 59.58 & 109.27 & 11.05 & 48.67 & 89.58 & 0.02 & 0.06 & 0.04 \\
\hline \multicolumn{11}{|c|}{ Main effects } \\
\hline \multicolumn{11}{|l|}{ Na level } \\
\hline Low & & 253.4 & $1,666.6$ & $3,494.3$ & 218.2 & $1,243.2$ & $2,403.1$ & $1.16^{a}$ & 1.34 & 1.46 \\
\hline Mid & & 245.1 & $1,654.9$ & $3,446.0$ & 219.4 & $1,289.7$ & $2,329.3$ & $1.12^{b}$ & 1.29 & 1.48 \\
\hline High & & 241.4 & $1,651.3$ & $3,379.0$ & 213.3 & $1,283.0$ & 2,303.6 & $1.13^{\mathrm{ab}}$ & 1.29 & 1.47 \\
\hline \multicolumn{11}{|l|}{ Phytase } \\
\hline \multicolumn{11}{|c|}{ Phytase } \\
\hline & None & 247.8 & $1,638.8$ & $3,445.6$ & 217.5 & $1,246.1$ & $2,354.5$ & 1.14 & 1.32 & 1.46 \\
\hline & Plus & 245.5 & $1,676.4$ & $3,434.1$ & 216.4 & $1,298.0$ & $2,336.2$ & 1.14 & 1.30 & 1.47 \\
\hline \multicolumn{11}{|c|}{ Source of variation } \\
\hline $\mathrm{Na}$ & & ns & ns & ns & ns & ns & ns & * & ns & ns \\
\hline Phytase & & ns & ns & ns & ns & ns & ns & ns & ns & ns \\
\hline $\mathrm{Na} \times$ phy & & ns & ns & ns & ns & ns & ns & ns & ns & ns \\
\hline \multicolumn{11}{|c|}{ Means were obtained from 6 replicates (6-8) birds per cage. } \\
\hline \multicolumn{11}{|c|}{ a,b Means within a column without common superscript are statistically different $(p<0.05)$. } \\
\hline \multicolumn{11}{|c|}{ 1)Low, $1.5 \mathrm{~g} \mathrm{Na} / \mathrm{kg}$; Mid, 2.5 Na/kg; High, $3.5 \mathrm{~g} \mathrm{Na} / \mathrm{kg}$. } \\
\hline \multicolumn{11}{|c|}{${ }^{2)}$ None, without phytase; plus, with (500 U/kg) phytase. } \\
\hline${ }^{\text {ns }} p>0.05$ & $<0.05$ & & & & & & & & & \\
\hline
\end{tabular}

\section{Apparent metabolizable energy and ileal digestibility}

The interaction between $\mathrm{Na}$ and phytase influenced the apparent metabolizable energy (AME and ileal digestibility of $\mathrm{Ca}$ and $\mathrm{Mg}$ (Table 6). High $\mathrm{Na}$ diets with phytase supplementation showed improved $(\mathrm{Na} \times$ phytase, $p<0.001)$ AME value compared to high-Na diet without phytase. The high-Na diet reduced the digestibility of $\mathrm{Ca}(\mathrm{Na} \times$ phytase, $p<0.02)$ which was countered by phytase supplementation. Similarly, the negative effect of low and high $\mathrm{Na}$ diets on $\mathrm{Mg}$ digestibility was alleviated $(\mathrm{Na} \times$ phytase, $p$ $<0.05$ ) by phytase supplementation. The interaction between $\mathrm{Na}$ and phytase also tended $(p=0.075)$ to decrease the P digestibility, where the negative effect of high $\mathrm{Na}$ was compensated by phytase supplementation. The digestibility of $\mathrm{Na}$ was highest $(p<0.001)$ in high-Na diets and was negative in low and mid-Na diets. Dietary $\mathrm{Na}$, phytase or their interaction had no effect on $\mathrm{K}$ digestibility.

\section{Total tract retention of minerals}

Diets containing mid and high $\mathrm{Na}$ reduced $(\mathrm{Na} \times$ phytase, $p<$
0.001) the retention of $\mathrm{N}$ and $\mathrm{Ca}$ which was counterbalanced be phytase supplementation (Table 7). Phytase supplemented to low and high $\mathrm{Na}$ diets improved $(\mathrm{Na} \times$ phytase, $p<0.001)$ the $\mathrm{P}$ retention compared to the mid-Na diets with phytase. Low $\mathrm{Na}$ diets with phytase supplementation showed the highest $(\mathrm{Na} \times$ phytase, $p$ $<0.001)$ retention of $\mathrm{Na}, \mathrm{K}$ and $\mathrm{Mg}$ compared to mid and high $\mathrm{Na}$ diets with phytase.

\section{Bone development and mineral contents}

Dietary $\mathrm{Na}$, phytase and their interaction had no effect $(p>0.05)$ on length, width, breaking strength, ash and mineral content of tibia bone (data not shown).

\section{Protein content and enzyme activities in jejunum}

Phytase supplementation to high-Na diets improved $(\mathrm{Na} \times$ phytase, $p<0.001)$ the activities of AP, Ca-ATPase and Mg-ATPase compared to low or mid-Na diets with phytase (Table 8). Birds that received phytase-supplemented mid-Na diet showed the 
Table 5. Influence of dietary $\mathrm{Na}$ level and supplemental phytase on the ileal $\mathrm{pH}$, excreta $\mathrm{DM}$, ammonia and uric acid concentration of 22-24-day old broilers

\begin{tabular}{llcccc}
\hline Na levle $^{1)}$ & Phytase $^{2)}$ & lleal pH & DM (\%) & $\begin{array}{c}\text { Ammonia } \\
(\mathbf{m g} / \mathbf{L})\end{array}$ & $\begin{array}{c}\text { Uric acid } \\
(\mathbf{g} / \mathbf{L})\end{array}$ \\
\hline Low & None & 6.24 & 24.8 & $39.8^{\mathrm{a}}$ & 16.0 \\
& Plus & 6.02 & 25.0 & $39.4^{\mathrm{a}}$ & 17.6 \\
Mid & None & 6.04 & 23.4 & $33.3^{\mathrm{ab}}$ & 25.1 \\
& Plus & 6.00 & 22.6 & $34.9^{\mathrm{ab}}$ & 29.3 \\
High & None & 6.61 & 20.7 & $30.1^{\mathrm{b}}$ & 32.0 \\
& Plus & 6.54 & 20.1 & $37.9^{\mathrm{a}}$ & 30.2 \\
SEM & & 0.44 & 1.23 & 0.33 & 0.84 \\
Main effects & & & & & \\
Na level & & & & & \\
Low & & 6.13 & $24.9^{\mathrm{a}}$ & 32.6 & $16.8^{\mathrm{b}}$ \\
Mid & & 6.02 & $23.0^{\mathrm{a}}$ & 34.1 & $27.2^{\mathrm{a}}$ \\
High & & 6.57 & $20.4^{\mathrm{b}}$ & 34.0 & $31.1^{\mathrm{a}}$ \\
& & & & & \\
& Phytase & & 23.0 & $27.7^{\mathrm{b}}$ & 24.4 \\
& None & 6.29 & 22.6 & $37.4^{\mathrm{a}}$ & 25.7
\end{tabular}

Source of variation

\begin{tabular}{lllll}
$\mathrm{Na}$ & $\mathrm{ns}$ & $* * *$ & $\mathrm{~ns}$ & $* * *$ \\
Phytase & $\mathrm{ns}$ & $\mathrm{ns}$ & $* * *$ & $\mathrm{~ns}$ \\
$\mathrm{Na} \times$ phytase & $\mathrm{ns}$ & $\mathrm{ns}$ & $* *$ & $\mathrm{~ns}$ \\
\hline
\end{tabular}

Means were obtained from 6 replicates (2 birds per cage).

${ }^{a, b}$ Means within a column without common superscript are statistically different $(p<0.05)$.

1)Low, $1.5 \mathrm{~g} \mathrm{Na} / \mathrm{kg}$; Mid, $2.5 \mathrm{Na} / \mathrm{kg}$; High, $3.5 \mathrm{~g} \mathrm{Na} / \mathrm{kg}$.

${ }^{2}$ None, without phytase; plus, with (500 U/kg) phytase.

${ }^{\text {ns }} p>0.05 ; " p<0.01 ; " * p<0.001$.

highest $(\mathrm{Na} \times$ phytase, $p<0.001)$ protein content in jejunal mucosa than those fed phytase-free mid-Na diet. Low-Na diets reduced $(p$ $<0.01)$ the activity of $\mathrm{Na}-\mathrm{K}-\mathrm{ATP}$ ase compared to mid-Na diets. The $\mathrm{Ca}-\mathrm{Mg}$-ATPase activity was decreased $(p<0.05)$ in birds fed the mid-Na diet than high-Na diets. Supplementation of phytase improved the activities of $\mathrm{Ca}-\mathrm{Mg}$-ATPase $(p<0.05)$ and $\mathrm{Na}-\mathrm{K}-$ ATPase $(p<0.001)$. The interaction between $\mathrm{Na}$ and phytase was not significant for $\mathrm{Ca}-\mathrm{Mg}$-ATPase and $\mathrm{Na}-\mathrm{K}$-ATPase.

\section{Discussion}

In the current study, different levels of dietary $\mathrm{Na}$ had no effect on BWG and FI, which is in agreement with previous studies [18,19]. Similarly, Goodgame et al. [20] reported no significant effect on the productive performance of birds by increasing $\mathrm{Na}$ concentration from 1.6 to $2.8 \mathrm{~g} / \mathrm{kg}$ in diets. On the other hand, $\mathrm{Na}$ level below $1.6 \mathrm{~g} / \mathrm{kg}$ [20] and above $3.5 \mathrm{~g} / \mathrm{kg}$ could be detrimental to broiler performance [12]. Although, with the current experimental diets, $\mathrm{Na}(1.5$ to $3.5 \mathrm{~g} / \mathrm{kg})$ concentration exceeded the recommended level of NRC [6] and Aviagen [15] (1.5-2.0 g/kg and 1.6-2.0/2.3 $\mathrm{g} / \mathrm{kg}$, respectively), the lack of any significant variation in BWG and FI due to different dietary Na levels could be an indication of the bird's capacity to tolerate a wide range of $\mathrm{Na}$. There were no significant differences in BWG, FI and FCR of broilers fed diet supplemented with phytase at any stage of rearing compared to those fed non-supplemented diets. The lack of any phytase effect on performance of broilers indicates that the dietary adjustments for $\mathrm{AvP}, \mathrm{Ca}$, and $\mathrm{Na}$ from phytase inclusion currently used in practical diet formulation are justified. Enzyme supplementation had no effect because the mineral matrix was considered. This is a cost saving on diet formulation and is widely practiced under practical conditions [21].

Excreta DM content decreased in chickens fed high $\mathrm{Na}$ diets, irrespective of phytase supplementation, and this result is consistent with the previous findings [12]. Feeding diets containing $\mathrm{Na}$ level more than $3.0 \mathrm{~g} / \mathrm{kg}$ increased the water consumption of birds, with the consequence that the excreta had higher moisture content. It has been reported that supplementation of diets with phytase increased litter moisture content [13], no such effect was observed in the present study. Assigning $\mathrm{Na}$ matrix value of phytase in the present study diets may be a possible reason for not observing a phytase-induced wet litter problem. High dietary $\mathrm{Na}$ increased the uric acid concentration of excreta, while phytase supplementation and their interaction had no effect. As most excreta $\mathrm{N}$ is converted into uric acid before passing out through droppings, an increased excretion of uric acid in birds on high $\mathrm{Na}$ diets might be an indication of excess $\mathrm{N}$ loss. This result is also consistent with low retention of $\mathrm{N}$ observed with high $\mathrm{Na}$ diets.

Phytase supplementation to high $\mathrm{Na}$ diets increased the ammonia concentration in litter but the reason for this trend is not very clear. High moisture content in the litter partly explains the increased concentration of ammonia in the aforementioned diet. Although, it has been reported that high protein diets enhanced the excretion of $\mathrm{N}$ and ammonia [22], which is not the case in the present study as all experimental diets contained an equal amount of crude protein. However, there could be a general increase in protein loss due to the increase in protein digestibility, in the presence of phytase. There is a need for further investigation into this area.

Phytase supplementation improved AME, especially in diets with a high level of $\mathrm{Na}(3.5 \mathrm{~g} / \mathrm{kg})$ in the diet. This result is in agreement with Ravindran et al. [12], who reported better AME in birds that received diets containing $2.0-3.5 \mathrm{~g} / \mathrm{kg} \mathrm{Na}$ (equivalent to 225 to $300 \mathrm{mEq} / \mathrm{kg}$ ) supplemented with phytase. These researchers also suggested that phytase supplementation had no effect on AME when dietary $\mathrm{Na}$ exceeded the above-mentioned 
Table 6. AME and ileal digestibility coefficient of minerals of 24-d old broilers that consumed diets with different levels of Na with or without phytase

\begin{tabular}{|c|c|c|c|c|c|c|c|c|}
\hline Na level ${ }^{11}$ & Phytase $^{2)}$ & AME (MJ/kg) & $\mathbf{N}$ & $\mathrm{Ca}$ & $\mathbf{P}$ & $\mathrm{Na}$ & $\mathrm{K}$ & $\mathrm{Mg}$ \\
\hline \multirow[t]{2}{*}{ Low } & None & $14.92^{\mathrm{ab}}$ & 0.75 & $0.47^{a}$ & 0.50 & -0.56 & 0.85 & $0.12^{b}$ \\
\hline & Plus & $14.92^{\mathrm{ab}}$ & 0.80 & $0.38^{\mathrm{a}}$ & 0.54 & -0.45 & 0.89 & $0.30^{\mathrm{a}}$ \\
\hline \multirow[t]{2}{*}{ Mid } & None & $14.95^{\mathrm{ab}}$ & 0.76 & $0.38^{\mathrm{a}}$ & 0.46 & 0.05 & 0.89 & $0.16^{\mathrm{ab}}$ \\
\hline & Plus & $14.88^{\mathrm{ab}}$ & 0.79 & $0.33^{\mathrm{a}}$ & 0.47 & -0.25 & 0.87 & $0.16^{\mathrm{ab}}$ \\
\hline \multirow[t]{2}{*}{ High } & None & $14.06^{c}$ & 0.71 & $0.16^{\mathrm{b}}$ & 0.31 & 0.19 & 0.87 & $-0.12^{\mathrm{c}}$ \\
\hline & Plus & $15.22^{\mathrm{a}}$ & 0.78 & $0.39^{\mathrm{a}}$ & 0.50 & 0.13 & 0.90 & $0.17^{\mathrm{ab}}$ \\
\hline SEM & & 0.03 & 0.02 & 0.08 & 0.06 & 0.25 & 0.02 & 0.08 \\
\hline \multicolumn{9}{|l|}{ Na level } \\
\hline Low & & 14.9 & 0.78 & $0.43^{\mathrm{a}}$ & $0.52^{\mathrm{a}}$ & $-0.50^{\mathrm{b}}$ & 0.87 & $0.21^{a}$ \\
\hline Mid & & 14.8 & 0.77 & $0.36^{\mathrm{ab}}$ & $0.47^{\mathrm{ab}}$ & $-0.10^{b}$ & 0.88 & $0.16^{\mathrm{ab}}$ \\
\hline \multirow[t]{4}{*}{ High } & & 14.6 & 0.75 & $0.27^{\mathrm{b}}$ & $0.41^{b}$ & $0.16^{\mathrm{a}}$ & 0.88 & $0.03^{b}$ \\
\hline & Phytase & & & & & & & \\
\hline & None & $14.6^{\mathrm{b}}$ & $0.74^{\mathrm{b}}$ & 0.37 & $0.43^{b}$ & -0.11 & 0.87 & $0.05^{b}$ \\
\hline & Plus & $14.9^{\mathrm{a}}$ & $0.79^{\mathrm{a}}$ & 0.34 & $0.51^{\mathrm{a}}$ & -0.19 & 0.88 & $0.21^{a}$ \\
\hline \multicolumn{9}{|c|}{ Source of variation } \\
\hline $\mathrm{Na}$ & & ns & ns & * & * & $* * *$ & ns & ** \\
\hline Phytase & & * & $* * *$ & ns & * & ns & ns & *** \\
\hline $\mathrm{Na} \times$ phytase & & $* * *$ & ns & * & ns & ns & ns & * \\
\hline
\end{tabular}

\footnotetext{
Means were obtained from 6 replicates ( 2 birds per cage).

${ }^{a-c}$ Means within a column without common superscript are statistically different $(p<0.05)$.

${ }^{1)} \mathrm{Low}, 1.5 \mathrm{~g} \mathrm{Na} / \mathrm{kg}$; Mid, $2.5 \mathrm{Na} / \mathrm{kg}$; High, $3.5 \mathrm{~g} \mathrm{Na} / \mathrm{kg}$.

${ }^{2)}$ None, without phytase; plus, with $(500 \mathrm{U} / \mathrm{kg}$ ) phytase.

${ }^{\text {ns }} p>0.05 ;{ }^{*} p<0.05 ;{ }^{* *} p<0.01 ; " * * 0.001$.

AME, apparent metabolizable energy.
}

range. Although not significant, high-Na diet reduced the digestibility of $\mathrm{N}$, similar to previous results [12,23]. This result suggests that $\mathrm{N}$ utilization is less likely to improve in high $\mathrm{Na}$ diets, which is consistent with excess urinary loss of uric acid.

It has been speculated that supplementation of phytase in diet substantially reduces the phytate/phytate-protein induced hypersecretion of gastric acid, digestive enzymes (pepsin and mucin) and $\mathrm{NaHCO}_{3}[12,24]$. Recent studies [10,12,25-27] reported that phytase inclusion in diet significantly improved the ileal $\mathrm{Na}$ digestibility and suggested possible reduction of $\mathrm{Na}$ inclusion level in phytase supplemented diet. This is in contrast with present study where phytase had no effect on ileal $\mathrm{Na}$ digestibility at different dietary $\mathrm{Na}$ levels. The reason of this discrepancy is not clear. The use of $\mathrm{Na}$ matrix value of phytase in the diet formulation of the present study may partly justify the lack of response of ileal $\mathrm{Na}$ digestibility to phytase. However, almost all of the aforementioned studies, including the present one; obtained negative digestibility coefficients for $\mathrm{Na}$, which may be due to excessive secretion of endogenous $\mathrm{Na}$, a process that would vary with the feeding status of birds. Due to complex $\mathrm{Na}$ and $\mathrm{Cl}$ flux in the intestine, it is sometimes unrealistic to make inferences on the trend of their digestibility in the small intestine [10]. However, increasing $\mathrm{Na}(3.5 \mathrm{~g} / \mathrm{kg})$ concentrations in diets resulted in significant improvements in ileal digestibility of $\mathrm{Na}$ but reduced total tract $\mathrm{Na}$ retention. This is partly consistent with the findings of Ravindran et al. [12], who suggested a possible influence of dietary $\mathrm{Na}$ on intestinal secretion and absorption of $\mathrm{Na}$ in poultry.

Phytase-mediated retention of $\mathrm{Na}$ was mostly observed with the diet containing $1.5 \mathrm{~g} \mathrm{Na} / \mathrm{kg}$ and there was significant interaction between $\mathrm{Na}$ and phytase, which indicates possibility of reduction of dietary $\mathrm{Na}$ need in poultry diets when supplemented with phytase. However, this may not be correct as the interaction between phytase and $\mathrm{Na}$ for overall performance and nutrient utilization of broilers was not consistent with total $\mathrm{Na}$ retention data. Besides, previous study [28] reported that that the chloride ion of salt $(\mathrm{NaCl})$ electrostatically competes with phytate and reduces the phytateprotein complex formation (including digestive enzyme, trypsin, and substrate protein) and consequently attenuates the negative effect of protein-phytate complex in diets supplemented with phytase. Therefore, the association between $\mathrm{Na}$ and phytase in light of 
Table 7. Effect of $\mathrm{Na}$ on total tract retention of nitrogen $(\mathrm{N})$ and minerals of 24-d old broilers fed diet with or without phytase

\begin{tabular}{llllllll}
\hline $\begin{array}{c}\text { Na } \\
\text { level }\end{array}$ & Phytase $^{2)}$ & $\mathbf{N}$ & $\mathbf{C a}$ & $\mathbf{P}$ & $\mathbf{M g}$ & $\mathrm{Na}$ & $\mathbf{K}$ \\
\hline Low & None & $0.65^{\mathrm{ab}}$ & $0.60^{\mathrm{a}}$ & $0.56^{\mathrm{b}}$ & $0.25^{\mathrm{a}}$ & $0.64^{\mathrm{b}}$ & $0.35^{\mathrm{b}}$ \\
& Plus & $0.67^{\mathrm{a}}$ & $0.58^{\mathrm{a}}$ & $0.62^{\mathrm{a}}$ & $0.29^{\mathrm{a}}$ & $0.73^{\mathrm{a}}$ & $0.42^{\mathrm{a}}$ \\
Mid & None & $0.61^{\mathrm{b}}$ & $0.50^{\mathrm{b}}$ & $0.49^{\mathrm{c}}$ & $0.18^{\mathrm{a}}$ & $0.41^{\mathrm{d}}$ & $0.28^{\mathrm{c}}$ \\
& Plus & $0.65^{\mathrm{ab}}$ & $0.56^{\mathrm{a}}$ & $0.55^{\mathrm{b}}$ & $0.21^{\mathrm{a}}$ & $0.47^{\mathrm{c}}$ & $0.29^{\mathrm{bc}}$ \\
High & None & $0.50^{\mathrm{c}}$ & $0.27^{\mathrm{c}}$ & $0.28^{\mathrm{d}}$ & $-0.13^{\mathrm{b}}$ & $0.09^{\mathrm{f}}$ & $0.09^{\mathrm{d}}$ \\
& Plus & $0.67^{\mathrm{a}}$ & $0.60^{\mathrm{a}}$ & $0.63^{\mathrm{a}}$ & $0.26^{\mathrm{a}}$ & $0.35^{\mathrm{e}}$ & $0.35^{\mathrm{b}}$ \\
SEM & & 0.05 & 0.03 & 0.02 & 0.06 & 0.02 & 0.03 \\
Main effects & & & & & & \\
Na level & & $0.65^{\mathrm{a}}$ & $0.59^{\mathrm{a}}$ & $0.59^{\mathrm{a}}$ & $0.27^{\mathrm{a}}$ & $0.68^{\mathrm{a}}$ & $0.39^{\mathrm{a}}$ \\
Low & $0.63^{\mathrm{a}}$ & $0.53^{\mathrm{b}}$ & $0.52^{\mathrm{b}}$ & $0.20^{\mathrm{a}}$ & $0.44^{\mathrm{b}}$ & $0.25^{\mathrm{b}}$ \\
Mid & $0.59^{\mathrm{b}}$ & $0.44^{\mathrm{c}}$ & $0.46^{\mathrm{c}}$ & $0.08^{\mathrm{b}}$ & $0.22^{\mathrm{c}}$ & $0.22^{\mathrm{c}}$
\end{tabular}

High

Phytase

$\begin{array}{lllllll}\text { None } & 0.58^{\mathrm{b}} & 0.46^{\mathrm{b}} & 0.44^{\mathrm{b}} & 0.10^{\mathrm{b}} & 0.38^{\mathrm{b}} & 0.24^{\mathrm{b}} \\ \text { Plus } & 0.66^{\mathrm{a}} & 0.58^{\mathrm{a}} & 0.60^{\mathrm{a}} & 0.26^{\mathrm{a}} & 0.52^{\mathrm{a}} & 0.35^{\mathrm{a}}\end{array}$

Source of variation

\begin{tabular}{lllllll}
$\mathrm{Na}$ & $* * *$ & $* * *$ & $* * *$ & $* * *$ & $* * *$ & $* * *$ \\
Phytase & $* * *$ & $* * *$ & $* * *$ & $* * *$ & $* * *$ & $* * *$ \\
$\mathrm{Na}$ × phytase & $* * *$ & $* * *$ & $* * *$ & $* * *$ & $* * *$ & $* * *$ \\
\hline
\end{tabular}

Means were obtained from 6 replicates ( 7 birds per cage).

${ }^{a-d}$ Means within a column without common superscript are statistically different $(p<0.05)$.

${ }^{1)}$ Low, $1.5 \mathrm{~g} \mathrm{Na} / \mathrm{kg}$; Mid, $2.5 \mathrm{Na} / \mathrm{kg}$; High, $3.5 \mathrm{~g} \mathrm{Na} / \mathrm{kg}$.

${ }^{2)}$ None, without phytase; plus, with $(500 \mathrm{U} / \mathrm{kg})$ phytase.

$p<0.001$.

$\mathrm{Cl}$ effect is worthy of consideration.

Phytase supplementation improved the activity of $\mathrm{Na}-\mathrm{K}-$ ATPase, which is in agreement with previous report [29]. These researchers established that phytase dephosphorylation ameliorates the negative effect of phytate on Na-K-ATPase activity in the intestine of chickens. As Na-K-ATPase maintains electrochemical gradients across the gut mucosa, it is possible that phytase also improved the absorption and intestinal uptakes of $\mathrm{Na}$ and other co-transported nutrients [30]. This is consistent with the phytase-related improvement of digestibility and retention of minerals in the present study. The reduction of Na-K-ATPase activity of the jejunum in birds offered low-Na diets is paltry in agreement with previous study [31]. This finding suggests that as the Na-dependent transport system and Na-K-ATPase activity in the intestine are responsible for absorption of most of the nutrients, thus, provision of sufficient $\mathrm{Na}$ to diets is essential to ensure the efficient activity of these enzymes and subsequent nutrient absorption as well [32].
The digestibility of $\mathrm{Ca}$ and $\mathrm{Mg}$ was reduced in birds that consumed the high- $\mathrm{Na}(3.5 \mathrm{~g} / \mathrm{kg})$ diets, which was compensated by phytase supplementation. This partly agrees with the previous findings where increasing $\mathrm{Na}$ level in phytase-supplemented diets from 1.7 to $2.4 \mathrm{~g} / \mathrm{kg}$ (equivalent to 234 and $266 \mathrm{mEq} / \mathrm{kg}$ of $\mathrm{DEB}$, respectively) reduced the digestibility of the aforementioned minerals. In contrast, similar study [10] observed no such effect of different levels of $\mathrm{DEB}$ on $\mathrm{Ca}$ and $\mathrm{P}$ digestibility. Moreover, phytase improved the digestibility of $\mathrm{P}$ irrespective of $\mathrm{Na}$ levels which indicates that phytase was effective in releasing this mineral. Birds offered high $\mathrm{Na}$ diets showed poor retention of $\mathrm{Ca}$ and $\mathrm{P}$, but this effect was counteracted by phytase supplementation indicating a significant $\mathrm{Na}$ and phytase interaction. This finding is in agreement with previous study [12] where similar effect of DEB, phytase and $\mathrm{DEB} \times$ phytase interactions on total tract retention of $\mathrm{Ca}$ and $\mathrm{P}$ was observed.

\section{Conclusion}

The results of the present study showed that $\mathrm{Na}$ concentration in diets ranging from 1.5 to $3.5 \mathrm{~g} / \mathrm{kg}$ had no significant effects on bird performances with or without phytase supplementation. The improved AME value in phytase-supplemented diets further confirms the extra phosphoric effect of phytase, even with a wide range of $\mathrm{Na}$. Inclusion of $\mathrm{Na}$ at $3.5 \mathrm{~g} / \mathrm{kg}$ to diets negatively affected the utilization of minerals except for $\mathrm{Na}$, which implies that maintaining $\mathrm{Na}$ level at around $2.5 \mathrm{~g} / \mathrm{kg}$ is optimal for performance and mineral utilization. A higher $\mathrm{Na}$ level can sometimes compromise the retention and digestibility of $\mathrm{Ca}, \mathrm{P}$, and $\mathrm{Na}$, not by affecting phytate hydrolysis but by altering the absorption and reabsorption pattern of nutrients in the intestine. Despite data showing some interaction effect between $\mathrm{Na}$ and phytase for mineral utilization and enzyme activities, it is unclear, due to the inconsistent pattern of the data, whether $\mathrm{Na}$ level had any effect on phytase activity. Therefore, further investigation is warranted to explore the $\mathrm{Na}$ effect on phytase-induced nutrient digestibility and intestinal enzyme activities, especially when the $\mathrm{Na}$ content of the phytase matrix is considered.

\section{Competing interests}

No potential conflict of interest relevant to this article was reported.

\section{Funding sources}

This project was funded by University of New England, Australia and $\mathrm{AB}$ Vista, UK.

\section{Acknowledgments}

We express our sincere gratitude to the staff of Centre for Animal 
Table 8. Effect of different levels of dietary Na with or without microbial phytase on total protein $(\mathrm{mg} / \mathrm{g})$ content, alkaline phosphatase (AP; $\mu \mathrm{M} / \mathrm{mg}$ protein/mn) Ca-, Mg-, Ca-Mg-ATPase, and Na-K-ATPase ( $\mathrm{nmol} / \mathrm{mg}$ protein/ $\mathrm{min}$ ) activityof jejunum mucosa

\begin{tabular}{|c|c|c|c|c|c|c|c|}
\hline Na level ${ }^{1)}$ & Phytase $^{2)}$ & Protein & AP & Ca-Mg ATPase & Ca-ATPase & Mg-ATPase & Na-K-ATPase \\
\hline \multirow[t]{2}{*}{ Low } & None & $53.53^{\mathrm{bc}}$ & $3.60^{a}$ & 168.06 & $164.21^{b}$ & $145.18^{c}$ & 49.92 \\
\hline & Plus & $53.13^{\mathrm{bc}}$ & $2.60^{\mathrm{c}}$ & 177.21 & $160.69^{b}$ & $158.67^{b}$ & 86.38 \\
\hline \multirow[t]{2}{*}{ Mid } & None & $55.20^{\mathrm{ab}}$ & $2.48^{\mathrm{c}}$ & 153.39 & $159.42^{b}$ & $190.20^{\mathrm{a}}$ & 73.58 \\
\hline & Plus & $57.82^{\mathrm{a}}$ & $3.01^{\mathrm{b}}$ & 162.85 & $170.77^{b}$ & $166.59^{b}$ & 98.17 \\
\hline \multirow[t]{2}{*}{ High } & None & $57.23^{\mathrm{a}}$ & $3.19^{b}$ & 165.48 & $165.84^{b}$ & $154.81^{\mathrm{bc}}$ & 65.13 \\
\hline & Plus & $50.85^{c}$ & $3.78^{\mathrm{a}}$ & 187.01 & $210.72^{a}$ & $180.53^{\mathrm{a}}$ & 85.39 \\
\hline SEM & & 0.17 & 0.03 & 1.49 & 1.65 & 0.88 & 1.09 \\
\hline \multicolumn{8}{|l|}{ Main effects } \\
\hline \multicolumn{8}{|l|}{ Na level } \\
\hline Low & & $53.33^{b}$ & $3.10^{\mathrm{b}}$ & $172.64^{\mathrm{ab}}$ & $162.45^{\mathrm{b}}$ & $151.92^{\mathrm{C}}$ & $68.15^{b}$ \\
\hline Mid & & $56.51^{\mathrm{a}}$ & $2.75^{\mathrm{c}}$ & $158.12^{b}$ & $165.10^{b}$ & $178.40^{\mathrm{a}}$ & $85.88^{a}$ \\
\hline \multirow[t]{4}{*}{ High } & & $54.04^{\mathrm{b}}$ & $3.48^{\mathrm{a}}$ & $176.25^{\mathrm{a}}$ & $188.28^{a}$ & $167.67^{b}$ & $75.26^{\mathrm{ab}}$ \\
\hline & Phytase & & & & & & \\
\hline & None & $55.32^{\mathrm{a}}$ & 3.09 & $162.31^{\mathrm{b}}$ & $163.16^{b}$ & $163.40^{\mathrm{a}}$ & $62.88^{\mathrm{b}}$ \\
\hline & Plus & $53.93^{b}$ & 3.13 & $175.69^{\mathrm{a}}$ & $180.73^{\mathrm{a}}$ & $168.60^{\mathrm{a}}$ & $89.98^{\mathrm{a}}$ \\
\hline \multicolumn{8}{|c|}{ Source of variation } \\
\hline $\mathrm{Na}$ & & $* * *$ & *** & * & *** & $* \star *$ & $* *$ \\
\hline Phytase & & * & n.s. & * & $* *$ & n.s. & $* * *$ \\
\hline $\mathrm{Na} \times$ Phytase & & $* * *$ & $* * *$ & ns & *** & $* * *$ & n.s. \\
\hline
\end{tabular}

Means were obtained from 6 replicates (2 birds per cage).

${ }^{a-c}$ Means within a column without common superscript are statistically different $(p<0.05)$.

${ }^{1)} \mathrm{Low}, 1.5 \mathrm{~g} \mathrm{Na} / \mathrm{kg}$; Mid, $2.5 \mathrm{Na} / \mathrm{kg}$; High, $3.5 \mathrm{~g} \mathrm{Na} / \mathrm{kg}$.

${ }^{2)}$ None, without phytase; plus, with (500 U/kg) phytase.

${ }^{\text {ns }} p>0.05 ;{ }^{*} p<0.05 ;{ }^{*} p<0.01 ;{ }^{* *} p<0.001$.

Research and Teaching (CART), University of New England, Australia for helping with the management of chicken during the study period.

\section{Availability of data and material}

Upon reasonable request, the datasets of this study can be available from the corresponding author.

\section{Authors' contributions}

Conceptualization: Akter M, Graham H, Iji PA.

Data curation: Akter M.

Formal analysis: Akter M.

Methodology: Akter M, Iji, PA.

Software: Akter M.

Validation: Iji PA.

Investigation: Akter M.

Writing - original draft: Akter M.

Writing - review \& editing: Graham H, Iji PA.

\section{Ethics approval and consent to participate}

All animal experiments were in accordance with the protocol approved by Animal Ethics Committee University of New England, Australia. (Ethics approval No: AEC14-053).

\section{ORCID}

Marjina Akter

Hadden Graham

https://orcid.org/0000-0001-6018-9990

https://orcid.org/0000-0002-1620-1726

Paul Ade

https://orcid.org/0000-0002-6981-6281

\section{References}

1. Borges SA, Fischer da Silva AV, Ariki J, Hooge DM, Cummings KR. Dietary electrolyte balance for broiler chickens exposed to thermoneutral or heat-stress environments. Poult Sci. 2003;82:428-35.

2. Mongin P. Recent advances in dietary anion-cation balance: applications in poultry. Proc Nutr Soc. 1981;40:285-94.

3. Gal-Garber O, Mabjeesh SJ, Sklan D, Uni Z. Nutrient trans- 
port in the small intestine: $\mathrm{Na}+\mathrm{K}+-\mathrm{ATPase}$ expression and activity in the small intestine of the chicken as influenced by dietary sodium. Poult Sci. 2003;82:1127-33.

4. Selle PH, Cowieson AJ, Cowieson NP, Ravindran V. Protein-phytate interactions in pig and poultry nutrition: a reappraisal. Nutr Res Rev. 2012;25:1-17.

5. Vieira SL, Penz AM Jr., Pophal S, Almeida JGD. Sodium requirements for the first seven days in broiler chicks. J Appl Poult Res. 2003;12:362-70.

6. National Research Council [NRC]. Nutrient requirements of poultry. 9th ed. Washington, DC: National Academy Press; 1994.

7. Selle PH, Ravindran V. Microbial phytase in poultry nutrition. Anim Feed Sci Technol. 2007;135:1-41.

8. Akter M, Graham H, Iji PA. Interactions between phytase and different dietary minerals in in vitro systems.J Food Agric Environ. 2015;13:38-44.

9. Cowieson AJ, Acamovic T, Bedford MR. The effects of phytase and phytic acid on the loss of endogenous amino acids and minerals from broiler chickens. Br Poult Sci. 2004;45:101-8.

10. Ravindran V, Morel PCH, Partridge GG, Hruby M, Sands JS. Influence of an Escherichia coli-derived phytase on nutrient utilization in broiler starters fed diets containing varying concentrations of phytic acid. Poult Sci. 2006;85:82-9.

11. Adeola O, Cowieson AJ. Board-invited review: opportunities and challenges in using exogenous enzymes to improve nonruminant animal production. J Anim Sci. 2011;89:3189-218.

12. Ravindran V, Cowieson AJ, Selle PH. Influence of dietary electrolyte balance and microbial phytase on growth performance, nutrient utilization, and excreta quality of broiler chickens. Poult Sci. 2008;87:677-88.

13. Pos J, Enting H, Veldman A. Effect of phytase and dietary calcium level on litter quality and broiler performance. In: Proceeding of the 14th European Symposium on Poultry Nutrition; Lillehammer, Norway. 2003.

14. Akter M, Graham H, Iji PA. Response of broiler chickens to different levels of calcium, non-phytate phosphorus and phytase. Br Poult Sci. 2016;57:799-809.

15. Aviagen. Ross 308 broiler: nutrition specification, 2014. http:// en.aviagen.com/assets/Tech_Center/Ross_Broiler/Ross308BroilerNutritionSpecs2014-EN.pdf. Accessed at $18 \mathrm{Feb}$ 2018.

16. Akter MM, Graham H, Iji PA. Influence of different levels of calcium, non-phytate phosphorus and phytase on apparent metabolizable energy, nutrient utilization, plasma mineral concentration and digestive enzyme activities of broiler chickens. J Appl Anim Res. 2018;46:278-86.

17. Kageyama N. A direct colorimetric determination of uric acid in serum and urine with uricase - catalase system. Clin Chim Acta. 1971;31:421-6.

18. Oviedo-Rondon EO, Murakami AE, Furlan AC, Moreira I, Macari M. Sodium and chloride requirements of young broiler chickens fed corn-soybean diets (one to twenty-one days of age). Poult Sci. 2001;80:592-8.

19. Mushtaq MMH, Parvin R, Kim J. Carcass and body organ characteristics of broilers supplemented with dietary sodium and sodium salts under a phase feeding system. J Anim Sci Technol. 2014;56:1-7.

20. Goodgame SD, Mussini FJ, Lu C, Bradley CD, Comert N, Waldroup PW. Effect of phytase on the sodium requirement of starting broilers 2. Sodium chloride as sodium source. Int J Poult Sci. 2011;10:766-73.

21. Bedford MR, Walk CL, Masey O'Neill HV. Assessing measurements in feed enzyme research: phytase evaluations in broilers.J Appl Poult Res. 2016;25:305-14.

22. Hernandez F, Megias MD, Orengo J, Martinez S, Lopez MJ, Madrid J. Effect of dietary protein level on retention of nutrients, growth performance, litter composition and $\mathrm{NH}_{3}$ emission using a multi-phase feeding programme in broilers. Span J Agric Res. 2013;11:736-46.

23. Pereira Goncalves R. Influence of dietary electrolyte balance on phytase efficacy in poultry [MRes thesis]. Glasgow (UK): University of Glasgow; 2014. http://theses.gla.ac.uk/id/ eprint/5589. Accessed 16 October 2016.

24. Cowieson AJ, Acamovic T, Bedford MR. Phytic acid and phytase: implications for protein utilization by poultry. Poult Sci. 2006;85:878-85.

25. Selle PH, Ravindran V, Partridge GG. Beneficial effects of xylanase and/or phytase inclusions on ileal amino acid digestibility, energy utilisation, mineral retention and growth performance in wheat-based broiler diets. Anim Feed Sci Technol. 2009;153:303-13.

26. Truong HH, Bold RM, Liu SY, Selle PH. Standard phytase inclusion in maize-based broiler diets enhances digestibility coefficients of starch, amino acids and sodium in four small intestinal segments and digestive dynamics of starch and protein. Anim Feed Sci Technol. 2015;209:240-8.

27. Truong HH, Yu S, Peron A, Cadogan DJ, Khoddami A, Roberts TH, et al. Phytase supplementation of maize-, sorghumand wheat-based broiler diets with identified starch pasting properties influences phytate (IP6) and sodium jejunal and ileal digestibility. Anim Feed Sci Technol. 2014;198:248-56.

28. Bye JW, Cowieson NP, Cowieson AJ, Selle PH, Falconer RJ. Dual effects of sodium phytate on the structural stability and solubility of proteins. J Agric Food Chem. 2013;61:290-5.

29. Liu N, Ru YJ, Li FD, Cowieson AJ. Effect of diet containing 
phytate and phytase on the activity and messenger ribonucleic acid expression of carbohydrase and transporter in chickens. J Anim Sci. 2008;86:3432-9.

30. Therein AG, Blostein R. Mechanisms of sodium pump regulation. Am J Physiol Cell Physio. 2000;279:C541-66.

31. Sklan D, Noy Y. Hydrolysis and absorption in the small intes- tines of posthatch chicks. Poult Sci. 2000;79:1306-10.

32. Dersjant-Li Y, Awati A, Schulze H, Partridge G. Phytase in non-ruminant animal nutrition: a critical review on phytase activities in the gastrointestinal tract and influencing factors. J Sci Food Agric. 2015;95:878-96. 